Meta

Journal des traducteurs

Translators' Journal

\title{
Few Ad Libs on Communicative and Semantic Translation, Translators, Interpreters, their Teachers and their Schools
}

\section{Sergio Viaggio}

Volume 37, numéro 2, juin 1992

URI : https://id.erudit.org/iderudit/004561ar

DOI : https://doi.org/10.7202/004561ar

Aller au sommaire du numéro

Éditeur(s)

Les Presses de l'Université de Montréal

ISSN

0026-0452 (imprimé)

1492-1421 (numérique)

Découvrir la revue

Citer cet article

Viaggio, S. (1992). Few Ad Libs on Communicative and Semantic Translation, Translators, Interpreters, their Teachers and their Schools. Meta, 37(2),

278-288. https://doi.org/10.7202/004561ar
Résumé de l'article

On épilogue sur la dichotomie traduction sémantique et traduction communicative. On présente des considérations générales sur les traducteurs et leur profession et on traite de l'apprentissage des langues, des systèmes et des institutions d'éducation en illustrant toujours les idées et les opinions avec des analogies. 


\title{
FEW AD LIBS ON COMMUNICATIVE AND SEMANTIC TRANSLATION, TRANSLATORS, INTERPRETERS, THEIR TEACHERS AND THEIR SCHOOLS
}

SERGIO VIAGgIO

ONU, New York, USA

\begin{abstract}
Résumé
On épilogue sur la dichotomie traduction sémantique et traduction communicative. On présente des considérations générales sur les traducteurs et leur profession et on traite de l'apprentissage des langues, des systèmes et des institutions d'éducation en illustrant toujours les idées et les opinions avec des analogies.
\end{abstract}

The difference between what Newmark calls semantic and communicative translation is, to my mind, not so much a difference in translation proper, but in the approach to the text itself ${ }^{1}$. Communicative translation seeks to bring the text to its new audience, it looks upon it as a cultural artifact to be transferred to a new milieu in order for it to be used, enjoyed, assimilated by new people. This, in turn, normally requires a certain degree of adaptation. Semantic translation, on the other hand, views the text as a cultural artifact that is "borrowed" from its original environment to be "displayed" as it were in a museum (linguistic, ethnographic, sociological, historical) not in order to be used, but to be "studied," "compared". As a reader of American laws and regulations, I, an Argentine resident or visitor in the US, want to know what I can and what I cannot do; the way these texts may formally coincide with or diverge from the laws and regulations in Argentina is of marginal interest, if any: I am not out to collate legal systems but to use them. An Argentine jurist, on the other hand, may wish precisely to compare, not only contents, but forms, legal concepts and their specific linguistic framing.

An excellent Solomonic way out of the eternal dilemma is to be found in Walter Arndt's Pushkin Threefold. He has produced what may be the perfect solution to poetical translation: a) the original, for those who can use it (not necessarily understand it; I speak no German, but have used an original version of Faust to give myself an idea of the "music" while reading the lyrics in a horribly prosaic Spanish rehash); b) a semantic (not literal) version, from which we get as thorough an idea as English will allow of everything the Russian words "mean" (and since every text, let alone poetry, goes far beyond its sheer linguistic meaning, what we get is something akin to the back of a tapestry); and c) a stab at English poetry, a metric translation. The intermediate, semantic text proves invaluable to make us aware of whatever has been changed - invaluable as a philological tool, but not as a translation. It will be more useful to the scholar, the student of Russian literature, the linguist; in other words, the analyst, not the enjoyer. It will provide no aesthetic pleasure whatsoever; it will make no converts to poetry or Pushkin. It is definitely not the kind of text you would want to bring with you to a desert island. Needless to say, if you want to transform one of Shakespeare's sonnets into a sonnet in Spanish, the resulting piece would not sound "like" Shakespeare at all, it will — or in any 
case should - sound "like" Lope de Vega: a Spanish translator ought to be well nigh as good a poet as Lope who wants to do justice to such a great poet as Shakespeare.

What a semantic translation approaches, analyses and transfers is a mere linguistic artifact, and transforms it into another linguistic artifact. It can be a perfectly valid exercise with a perfectly valid purpose, a bit like a behavioural description of football: a pattern of behaviour, but hardly a game. Texts, on the other hand, texts as they are written, read, liked, disliked and used in real life, are much more than linguistic artifacts; the same as meals are much more than proteins and calories. They are definitely linguistic, of course, but not merely so: they are linguistic gels of cultural, psychological, aesthetic and a myriad other "facts". The average reader of the original - consciously or not - approaches them as such; and so will - consciously or not - the reader of the translation (and so does, by the way, the average author, and so should, of course, the average translator).

The epitome of such an approach is, perhaps, Nabokov's monstrous Eugene Onegin. Striving for fidelity to Pushkin's words, he ends up murdering Pushkin's poetry. Onegin's first four lines exhibit the following semantic meanings:

My uncle [is] of most honest rules[:]

when not in jest [he] has been taken ill,

he to respect him has forced [one],

and better invent could not...

The almost morphemic translation is by Nabokov himself. He then proceeds to put that into normal English - well, sort of:

My uncle has most honest principles:

when he was taken ill in earnest,

he has made one respect him

and nothing better could invent...

Who can read through 120 pages of that and enjoy it? I know the original almost by heart; I swear it says exactly that. Russians love those lines; how come? Simple: clothed in Russian, that ill-begotten sentence is a beauty. Fully aware that this other version takes semantic and other "liberties," it is the one I would nevertheless recommend to any lover of poetry:

My uncle, in the best tradition,

By falling dangerously sick

Won universal recognition

And could devise no better trick...

The unbelievable thing is that it is by Nabokov himself. No one but he could have come up with such a delightfully witty rendering. Pushkin would have been proud of such a translator. Yet Nabokov consciously and vehemently rejects the approach, favouring instead literalness, "rendering, as closely as associative and syntactical capacities of another language allow, the exact contextual meaning of the original. Only this is true translation" (1975: viii) " "Can a rhymed poem like Eugene Onegin be truly translated with the retention of its rhymes? The answer, of course, is no. To reproduce the rhymes and yet translate the entire poem literally is mathematically impossible" (ibid: ix). "In transposing Eugene Onegin from Pushkin's Russian into English I have sacrificed to completeness of meaning every formal element including the iambic rhythm, whenever its retention hindered fidelity. To my ideal of literalism I sacrificed everything (elegance, euphony, clarity, good taste, modern usage, and even grammar) that the dainty mimic prizes higher than truth. Pushkin has likened translators to horses changed at the 
posthouses of civilization. The greatest reward I can think of is that students may use my work as a pony" (ibid: $\mathrm{x}$ ). It occurs to me that such a semantic translator is a taxidermist, not a veterinarian; he deals with dead matter, not with life.

I should like to stress that I understand communicative translation in a very wide sense. A law should read like a law, a contract like a contract, an ad like an ad, a poem like a poem. Does this necessarily mean "cultural" adaptation? Well, yes and no. No, if it is understood as turning the Achaean heroes into modern day executives or GI's; no, if it means tribes of Israel dwelling in tepees and hunting for the buffalo. (That is not communicative translation, that is outright - and in principle legitimate - recreation; as a matter of fact it needn't be a translation at all, you can do it without leaving the source language, witness "West Side Story" vis-à-vis "Romeo and Juliet". I'm quite certain the "response" by the former's audience was much closer to the one the latter received at the Globe Theatre than to what it gets nowadays. If Nida were to take the bard's gospel to the West Side kids, he might have come up with such a version.) Yes, if it means turning an original text designed to produce an aesthetic effect into a translated text designed for the same purpose. What will determine the degree of "adaptation" - and therefore of "literalness" - will be, of course, the situation, in its all-encompassing sense, as developed by Neubert (1985): i.e. the vector resulting from all those countless factors both a text and its translation express and are embedded in. The situation may well necessitate total adaptation - seldom; or demand absolute literalness - almost never; or call for a semantic translation - sometimes; or leave no alternative to communicative translation - most of the time.

That translations (in the larger sense, including interpretations) by recognised practitioners are rarely communicative and most of the times semantic (when not quasiliteral) shows how few of them are done by truly qualified language specialists who do not simply know the languages and have the necessary grasp of the subject and are cultivated, but who are aware of all these options and are able to exercise them according to a fully mastered situation, i.e. people who have a thorough grasp of the factors obtaining in mediated verbal communication. The semantic translator, the communicative translator, the literal translator or the adapter ought to be the same practitioner, skillful enough to do it in any of these ways, and sufficiently knowledgeable to discern how to do what when; in other words, a true professional, and not just a one-character actor. Needless to say, in ours, as in any other profession, there are necessary and unavoidable degrees of specialisation: by genre, by subject (let alone language); but a good translator should be able to do everything with a minimum of competence, the same way a cardiologist should be able to treat a broken wrist. For that, intuition and competence at producing texts is not enough, a systematised conceptualisation of translation as a discipline is of the essence.

Does this degree of competence unavoidably require such a degree of theoretical elaboration, and does such a degree of theoretical elaboration demand so much reading and studying? Not necessarily... up to a point. Do you have to enrol at the Julliard School of Music in order to be able decently to play the piano? Of course not! Must you be able at least to read music? Absolutely not! Do you need, then, someone to teach you? What for! All you really require is talent: passive - a good ear, active - agile fingers; and if you not only wish to play but make music, what shall I call it, psychological - feeling, sense of rhythm, of harmony, of dynamics. No conservatory can give you that, all it can do is help you develop it if you have it in you to begin with. Will talent alone, though, suffice for you to play Bach professionally? Wouldn't it be much better and so much easier if you didn't have to discover inverted counterpoint all by yourself; if someone told you, at a lecture, over a cup of coffee or in a book, the difference between baroque 
conventions and ours, what is known about embellishments and tempos, and so much more? Once equipped with all that, you can still go and play like Backhaus or Landowska, but it will be a conscious, knowledgeable choice: at that time, nobody knew better, but now you do (which doesn't automatically make you a better musician, just a more developed musicologist, a devilish difference!). You can go the way of Glenn Gould or that of Trevor Pinnock; knowledge won't push you, just show you the possible way.

I must apologise for straying so often far afield, treading upon the toes of physicians and piano players, but our métier is so humiliatingly underrated. Even serious, responsible and competent translators do not seem to take their profession more than like a craft. How many know about this journal? How many have read one, just one book, article, paper on translation? And it's even worse perhaps in the case of interpreters. Among the colleagues I am personally acquainted with - and I am a witness to the professional ability of many - , even those who have formally studied translation acknowledge that they never have gone back to theory after graduation. Why? Obviously, their teachers failed to bring out the link between theory and practice; but I think the real answer lies somewhere along the path I now propose to embark upon.

Most good (and all of the bad) translators and interpreters never really set about to become interpreters or translators. They have come from the most diverse walks of life, with a good command of their languages, a natural talent and intelligence, sometimes even the knack for translation, and have suddenly found themselves with nothing better or more remunerative or lawful enough to do. Physicians, lawyers, economists, engineers, even musicians at one point or another have found themselves out of business, in exile, wanting a change of life, whatever; and like so many immigrants have arrived to look around for a while and stayed for good. It's a bit like my native Buenos Aires at the turn of the century: foreigners outnumbered natives (natives, in our case, being those who didn't specialise in anything but things translatological; those of us who chose our profession the way engineers, architects and conductors have chosen theirs. I, for one, did not). I know closely a few colleagues who undoubtedly rank among the most competent, and who literally detest the guts of their profession. It is that other thing they'd like to be doing. Some of them can't (a Peruvian law degree will be of little good in Sweden), others couldn't make a living out of it (try and feed a family by teaching Russian literature in Argentina), others could, but would be financially worse off. A dismal barometer is the flood of applications received annually at the Spanish section of U.N. from people in Latin America desperate to make a living, any kind of a living, elsewhere. Translation and interpretation have come to be the Foreign Legion of intellectuals: everybody having a professional past to forget seems to have joined up.

An architect, a sociologist, an opera singer wouldn't dream of not keeping abreast of the developments in their fields of activity, of new techniques, of new solutions to old problems, of all manner of insights; they simply could not survive otherwise. They are psychologically and professionally conditioned, as it were; they are an architect, social scientist, musician all day long. Most translators and interpreters leave their professional selves at the office, on the shelf, in the booth. They will learn new terms, of course, but not consciously seek to develop their mastery at manipulating language and communication. In that respect, they are like birds: every year the nest is built exactly the same way; even the good ones stop getting any better. I have tried to interest many a colleague in translatology... To absolutely no avail: a manual in plumbing would arouse more excitement. They just do not feel it has anything to do with their performance. It so happens they view themselves as nothing other than practitioners; and since language develops much more slowly than household appliances, they feel a much lesser need to 
update than electricians. A large proportion act as if they were nothing other than experienced bilinguals: amateurs now paid; amateurs turned - but not developed into professionals; and when they demand, even rightly so, equal treatment with other professionals, it is (psychologically at least) by virtue of their otherwise unconnected college degrees. Both the uneducated client and the merely pragmatic translator tend to assume, perhaps unconsciously, that, there being but one original, there is but one translation; all that is needed is someone to write it or utter it. It is not surprising that most clients will seek the best lawyer and yet engage the cheapest translator.

Underrating, like charity, begins at home. And here I feel we have hit the nail squarely on the head: many, perhaps most, people who call themselves translators and interpreters have no calling, no vocation. No wonder, then, that they will feel little interest, curiosity even, for anything not immediately connected with their immediate performance. No calling - no love. No love - no enthusiasm. At the 1991 AIIC Assembly, replying to my comments, the last speaker in the general debate on the profession averred that he had not come to talk theory, but conditions of work. Imagine a surgeon declaring at a meeting of an international association of physicians "I didn't come to discuss developments in open-heart surgery; I just want to know how much I can charge for the operation." Fortunately, our profession is quickly coming of age: more and more colleagues are now pondering theory, many theoreticians are now minding practice; translation, translating and linguistics have finally joined hands (and it is translators who have asked linguists to tango).

Translation (always in its wider sense, including interpretation) is the one activity where language, langue and parole come neatly and inescapably together; where there's no room for omissions or distortions; where the hits and misses of the likes of Saussure and Hjelmslev, Searle and Van Dijk, Wittgenstein and Russell can be appreciated in all their implications. It is still a relatively unexplored realm, but, on the other hand, how many fields of activity are left today where there is room for people such as so many of us to become pioneers? Nowadays, even if he is endowed with the genius of Archimedes, taking a bath won't lead the physicist to discover any new principle. We, on our part, are much closer to our Hippocrateses than physicians, and that is why we still have not been able academically, administratively and socially to discriminate the true scientists from the witch-doctors; they were very much mingled in the beginning too.

People know languages and wonder what to do with what they know to be an asset. Sometimes the idea comes from others: "You speak Spanish and English so well; why don't you become a translator?" Imagine someone saying "You are so good with numbers; why don't you become a mathematician?" Why does the comparison strike us as obviously wrong? There is a point where the analogy between translation and the other traditional professions no longer holds, and it has to do with the nature of the skills and knowledge involved, which are not that easily assimilable to the kind of skills and knowledge involved elsewhere. The crucial problem facing the "pédagotrad" 3 is that of the astonishingly deficient command of their native language his students can boast. That I can gauge, English in the US and Spanish in all of Latin America are woefully taught, clumsily learned, awkwardly spoken, and dismally written.

But, even if the situation were not so depressing, the mastery of his language even a gifted student acquires at school and home is definitely insufficient for a (good) translator or interpreter, i.e. for a language specialist. And there is the rub, for, throughout the world, colleges are meant, at least in theory, to pick up the young where school has left them. There exists an organic link between secondary and tertiary education. The student has been taught all the math, history, chemistry, physics and anatomy he needs in order to slide more or less comfortably into any traditional career. At worst, he requires a few 
months of intensive brushing-up cum supplementing and on he can go! He is not expected - nor could he be - to have learnt any of those subjects outside of the school system. The difference in levels at high school's end is more a function of the particular institute (with the unpleasant class element reigning supreme) than of the curricula. To the point that countries often recognise each other's high school diplomas, so that an Argentinean, for instance, can be admitted to college in Spain, or - provided he knows enough French - France. Now, if school has failed to teach the student his native tongue well enough, it is obvious that the knowledge of a foreign language it may have additionally bestowed will prove absurdly low for him to go on to becoming a translator from it - let alone into it. Here, either special tuition at a special bilingual school (both elementary and high) and/or a home where the foreign language is daily spoken by cultivated adults and/or a stay of some length in the relevant milieu (and not only country) will more often than not be necessary. Since all of these pre-requisites fall without the regular curriculum and, in most cases, are academically unquantifiable, schools for translators and interpreters are faced with the difficult task of specifying the criteria for admission: how many years of, say, English? What kind of years? Three hours a week at a rural school in North East Argentina? With an uncle in the South Bronx? Of course, one always has the admission test, thank God!

As to the foreign language, the intelligent use of dictionaries and acquaintances can help bridge many gaps. What about the gaps in one's own? We can conceive of inarticulate physicians or engineers (they do abound), and very good ones at that, but hardly of inarticulate specialists at writing or speaking. For most people, language is but a tool that need not be wielded too deftly in order to do its job. Likewise, the average ability to drive need not be greater than enough to park in less than two minutes. But that level of linguistic or automotive competence will hardly suffice for anybody to become a language specialist or race at Indianapolis. Besides, the mastery of a language cannot be weighted solely in linguistic terms: there's the cultural, both general and specific, which definitely goes far beyond what any school system can dream of teaching. I have come to realise that those swashbuckling stories I used to read as a child have taught me probably more geography and history than school did. All the nautical terms, the names of weapons and fortifications, and so much more I owe to Jules Verne, Emilio Salgari, Robert Louis Stevenson and their likes. I wonder whether youngsters read them nowadays, and where they get their notions and vocabulary if they no longer do.

When I grew up in suburban higher middle-class Buenos Aires, back in the fifties, my friends and I did a lot of reading. We all had parents who both could afford to buy the books and fostered the habit in us. A few were sent to private schools; I, for one, went from an English kindergarten through an English pre-school to an English elementary school, with both the English and Argentine curricula and top teachers forever fresh from the 'mother country'. By age ten, I was already thrilled by Lord Carnarvon and the curse of Tutankhamen and the chief of Xerxes's Immortals pierced in the throat by an Athenian spear at Marathon. More often than not, I would relinquish my toys just to listen while the grown-ups talked. Politics, economics, literature, cinema, art were widely and most entertainingly discussed by most of them in many homes. Already in high school - a regular public school this time around - specialists started emerging among us. There was Roberto, who read Freud; and Osvaldo, who talked of Bergman and Eisenstein; and Jorge, the advocate of existentialism and the writings of Sartre and Camus; and myself, the recalcitrant Beethovenian. By the time we all scattered, school had qualified us to take up any regular career. But when three years later I landed in Moscow to study Russian Language and Literature, I found that my sideline book-reading and movie- 
watching and talk-listening stood me in more effective stead than whatever I had been academically taught.

I have drifted into the autobiographical both because suddenly all those beloved names and faces have swarmed upon me and because I think that many among us have a similar story to tell. Which brings me back and down to where I left off: the unquantifiability of the knowledge, linguistic and of the world, that the translator or interpreter must possess. I've already mentioned that high school cannot hope to provide it. Can college? Can a translator-training institution? Naturally, it can and should make the student aware of his cultural lacunae and prod him into filling them; but no course in English and American Literature, or History, or Philosophy will suffice. Nor will any in Higher English Syntax. These institutions, at least in the capitalist world, must count on the student having acquired all of the relevant knowledge and competence on his own or, in any event, out of the academic "mainstream". The same situation obtains, I presume, in conservatories, where the violin one might have learnt at school simply won't do (and I very much doubt violin is part of the curriculum at any school in the third world).

But although we may assume that there will always be at least a few students with all the necessary qualifications to be admitted to a school for translators and interpreters, we can bet one area will have more often than not remained neglected if not wholly untrodden: that of grammar, syntax, poetics and stylistics of both languages, more specifically the active one, and, perhaps even more importantly, text analysis and production. To this very day, even if we count out all manner of hacks eking a living out of language switching, only a minute number of practising translators and interpreters, good or bad, have ever studied language and verbal communication scientifically, the way a physician must study anatomy, for instance. The result being that most translators and interpreters practise an intuitive craft rather than a discipline; (which does not necessarily rule out competence, witness the many excellent professionals with little or no theoretical training whatsoever).

That lack of theoretical knowledge, though not always in the way of good practitioners, will nevertheless prevent them from becoming effective pedagogues. The 'this-is-the-way-I-do-it' approach never really works. To be taught, and not merely transmitted, empiric know-how must become abstract know-why; practice needs to turn into theory (what is science, after all, but experience made awareness?). The "pédagotrad" ought to have a secure and wide theoretical grasp of the subject at hand, beginning, of course, by language itself and not only specific languages. He must be a linguist - in the widest possible sense - or become one. No amount of keyboard wizardry will land a pianist a professorship in any conservatory if he's not able to read music or does not know any theory.

It may be argued, as Shaw did, that those who can - do, while those who can't teach. Indeed; few of the great music teachers have been great artists themselves; but then few of the great artists have themselves been great teachers. It is equally arguable that those who can - teach, and those who can't - do. Neither statement is true: being inept at the one does not automatically qualify for the other; the skills required are different. Besides, one learns both from pedagogues and practitioners: the former explain, the latter show. I am not saying that practitioners can be dispensed with, I am just asserting that pedagogues should not; and I do indeed think they must be also practitioners themselves. The following paragraph, extracted from the otherwise unimpeachable Guide des établissements proposant des cours en interprétation de conférence, published by AIIC, makes woeful reading: "Bien sûr, tous les interprètes ne possèdent pas des dons pédagogiques certains, leur 'enseignement' n'a rien à voir avec l'enseignement traditionnel; leur tâche est plutôt de 'montrer', de guider, de simuler la réalité." (Version 
décembre 1985: 8)]. It is indeed sadly true. Nowhere in the qualifications this brochure prescribes for the interpreter-didactician is any theoretical knowledge of the workings of language (i.e. langage) to be found. The truth of the matter is, though, that being a genuine and effective "pédagotrad" demands the practical skill of the "trad" together with the theoretical knowledge of the "pédago".

This lack of qualified "pédagotrads" has its counterpart in the absence of a systematic methodological approach to the teaching of our discipline. Let us go back to the academic connection. Not only does high school prepare the student for any traditional career, but the different schools of medicine or chemistry go about forming their students roughly the same way; so much so that, as a rule, you can start medical school in Caracas and finish it in Stockholm; after all, Endocrinology is Endocrinology, and Epidemiology - Epidemiology. All medical students learn the same anatomy with different corpses at different universities in different countries. Specialisation comes later on. Some will become dermatologists and others will go into space medicine. Most will become anonymous practitioners. A few, being practitioners, will go on researching and developing as scientists. Even fewer will also tcach. Lastly there will be those for whom practice will have become secondary to theoretical study. But they will have all started together and for a long while followed the same path wherever they happened to be. And yet, how does, say, the first year at the Escuela Superior de Lenguas Vivas, in Buenos Aires, tie in with the second year at Binghamton? General Anatomy is taught at the first year of every medical school the world over, in Spanish, English, or Chinese. What about General Linguistics or Discourse Analysis in the translation/interpretation schools? What about Introduction to Translatology, for that matter?

Nobody, that I am aware, has come up with THE basic curriculum for a translation and interpretation school. Imagine if there were as many for medical schools! Also, most translation and interpretation schools dispatch their students in two or at most three years. Granted, as I have pointed out, knowledge of languages, previously acquired over several years, is not counted in. Yet students who enrol in a serious music school, such as Julliard, and who may have spent much more time and effort studying music, must complete four to six years. Why? Because they are prepared for a full-fledged career as full-fledged professionals. They may never get there, but they are left on the road to Carnegie Hall or La Scala. No wonder some professional musicians turn translators but few translators turn professional musicians; no wonder there are more people trained to be engineers who end up translating than translators who end up building bridges.

What actually happens is that those other professionals turned translators or interpreters 'climb down' from a savoir-faire based on a solid and systematised savoir to a mere savoir-faire: the converse is much harder. It would be a different story if the same systematised savoir were demanded from the translator or interpreter as well. It is high time our schools begin imparting precisely that. By now, enough universal principles have been established to warrant a universally scientific approach to translation (including interpretation), no matter what specific pair of languages is taken: That translation deals not with la langue but with la parole (or, if J.-C. Gémar prefers, language as used and not as a system); that it deals with texts that are always situated; that there is a fundamental distinction between linguistic meaning and extralinguistic sense; that equivalence is not measured bottom-up but should be sought at the text level. These concepts have to be instilled from the very outset, i.e. at the beginning of any course in whatever language from whatever language. Next should come more detailed translatological notions: Every student should know by first term's end what are dynamic and functional equivalence, semantic and communicative translation etc. The end-product ought to be a specialist in mediated verbal communication. Therefore, in every course 
there should be mandatory theoretical bibliography, with names such as Vinay and Darbelnet, Nida, Gile, Seleskovitch, Lederer, Delisle, García Landa or Schweitzer. The collections of Meta, Babel, The Interpreters' Newsletter, TTR, Target and the rest should be available for consultation in every department. Short of all that, it is at least possible to give an excellent general outlook through no more than five or six well-chosen articles 4 . Yet most students emerge on the other end of their training without having read an iota about translation; just commercial texts, legal texts, economic texts... Seldom, if ever, are they required to write a paper on translation.

In conservatories, not even the most dazzling would-be soloists get away with sheer virtuosity. The cymbals player who must sit through the whole 70 minutes of Bruckner's Seventh in order merely to play one single note - and it is not even a note $!^{5}$ - has had to study counterpoint. Our profession should not be 'easier' than that. Yes, anyone with a decent command of a given pair of languages and the subject in hand can come up with a decent translation; exactly the same way many a non-professional musician can play a decent Moonlight sonata. Indeed, a nurse may be able to tell you what's wrong with your stomach; only nobody would seek treatment from the nurse rather than the doctor. The difference, naturally, lies not in what the nurse can do as well as the doctor, but in what she cannot. And not only that; I remember a physician friend of my father's telling the following story: This patient had come to his surgery to be given an injection. She absolutely refused to allow the nurse to do it, demanding that the act be performed by the Galen himself. My father's friend obliged... and charged accordingly. The patient went wild: how dare he charge for the same injection seven times as much! "Because, dear madam," - came the reply - "the nurse learnt it in twelve months, whereas it took me seven years." If it were possible to sue translators and interpreters for malpractice, we could charge sevenfold too.

Unfortunately, nearly all of my colleagues at the U.N. - and, among them, some of the best the profession can boast at present - look pretty much down upon theory and anything remotely connected with it. "I didn't need any theory to get where I am," is their invariable riposte. With all due respect, it sounds to me a little like the rugged pioneer trying to convince his would-be agronomist son that "he don't need no books to farm good." As a matter of fact, neither did I actually need them to be where I was when I took them up, but I would have gotten there faster, better and saner. Having finally read them, nevertheless, has helped me become a better translator and interpreter - much as I have so far failed to convince any of my recalcitrant fellow Freemasons.

A few final thoughts: a translator should be an authority on languages the way a mechanic is an authority on cars. Only the theoretical knowledge of the laws of physics, nevertheless, will turn the mechanic into an engineer. Only the theoretical knowledge of the laws of verbal communication will distinguish the practitioner from the true language specialist. Books on translatology may be boring, but not much more than those on chemistry or pathology of infectious diseases. A translator or interpreter has no alibi for getting away with reading and learning less than a chemist or a veterinarian, unless, of course, he does not mind being considered and paid below them. In the final analysis, the standing of any profession will be equal to the standards it sets for itself.

Notes

1. For the reader unfamiliar with the concepts, may I give here a very succinct explanation: according to Newmark, what he calls 'authoritative' statements ought to be translated "as closely as the semantic and syntactic structures of the second language allow [reproducing] the exact contextual meaning of the original" (1981: 39 ). He calls this kind of translation 'semantic', as opposed to 'communicative', where the rendition "attempts to produce on its readers an effect as close as possible to that obtained on the readers of the original" (ibid.). 
2. Notice how his definition matches Newmark's almost word for word!

3. The term was coined, by J.-P. Vinay; I cannot help repeating three quotations I used in previous pieces. First, J.-C. Gémar: "Le personnage clé autour duquel s'articulent désormais les lignes de force de la théorie générale de la traduction... Mí-théoriciens mi-praticiens en ce sens qu'ils réfléchissent, à partir des conditions concrètes de leur expérience de traducteur, à la meilleure façon d'aborder les problèmes théoriques que pose la traduction et avancent des formules, des techniques et des méthodes pour la résoudre" (1983: 324 and 328). And now V. García Yebra: "...Un buen maestro se diferencia de un simple práctico en que no solo "hace," sino que "sabe el camino," conoce el método, para "hacer bien" lo que hace. Este saber, este conocimiento del camino, de las normas que es "visión" o "contemplación" ["What distinguishes a good teacher from a mere practitioner is that the former not only "does," but knows the way," the method, to "do it right." Such a knowledge of the way, of the norms governing the art of translating, is precisely the theoria, which is "vision" or "contemplation"] (1984:16-17); and "Yo admito que hay personas a quienes, en efecto, no puede enseñarse este arte. Pero esas personas, desgraciadamente, tampoco pueden aprenderlo por sí mismas. $Y$ las que son capaces de aprenderlo por sí mismas, sin maestros, a fuerza de práctica y experiencia, ... lo aprenderían más fácilmente, y acaso en grado más alto, si tuvieran buenos maestros" [I admit there are indeed people who cannot be taught this art. But, unfortunately, they cannot learn it on their own either. And those who are able to learn it on their own, without teachers, by dint of practice and experience... would learn it more easily, and perhaps to a higher degree, if they did have good teachers"] (ibid.: 21 ).

4. A list of articles that I have found to be illuminating, not too specialised, not too long, and of real practical value is given below in the annex. I asked my students at CUNY to read some of them and they all found them interesting and helpful. I have added my own papers on translation. The articles preceded by an asterisk I deem really indispensable.

5. And then only in the Nowak edition!

\section{BIBLIOGRAPHY}

ARNDT, W. (1972): Pushkin Threefold, N.Y., 454 p.

GARCIA YEBRA, V. (1984): Teoría y práctica de la traducción, Gredos, Madrid, 2 vols., 873 p.

GÉMAR. J-C. (1983): "De la pratique à la théorie, l'apport des praticiens à la theorie générale de la traduction", Meta, 28-4, pp. 323-333.

NEUBERT, A. (1985): Text and Translation, VEB Verlag Enzyklopdie, $165 \mathrm{p.}$

NEWMARK, P. (1981): Approaches to Translation, Pergamon Press, Oxford, 200 p.

PUSHKIN, A.S. (1975): Eugene Oneguin, a Novel in Verse. Translated from the Russian, with a Commentary, by Vladimir Nabokov. 2 Vols., Princeton University Press, $1374 \mathrm{p}$.

ANNEX

THE ARTICLES

BAGGE, CH. (1990): "Équivalence lexicale et traduction", Meta, 35-1, pp. 61-66.

BUHLER, H. (1979): "Suprasentential Semantics and Translation," Meta 24-4, pp. 451-458.

DARBELNET, J. (1977): "Niveaux de traduction", Babel, 23-1, pp. 6-17.

*DEJEAN LE FÉAL, K. (1987): “Putting Translation Theory into Practice," Babel, 33-4, pp. 205-211.

DELISLE, J. (1988): "L'initiation à la traduction économique", Meta, 33-2, pp. 204-215.

DEMERS, G. (1988): "L'enseignement de la traduction scientifique", Meta, 33-2, pp. 200-203.

FOLKART, B.(1984): "A Thing-Bound Approach to the Practice and Teaching of Technical Translation," Meta, 29-3, pp. 229-246.

FOLKART, B (1988): "Cohesion and the Teaching of Translation," Meta, 33-2, pp. 142-155.

GILE, D. (1986): "La traduction médicale doit-elle être réservée aux seuls traducteurs médecins? Quelques réflexions", Meta, 31-1, pp. 26-30.

GILE, D. (1986): "La compréhension des énoncés spécialisés chez le traducteur: quelques réflexions", Meta, 31-4, pp. 363-369.

GILE, D. (1982): "Fidélité et littéralité dans la traduction: une approche pédagogique", Babel, 28-1, pp. 34-36.

GILE, D. (1985): "De l'idée à l'énoncé: une expérience et son exploitation pédagogique dans la formation des traducteurs", Meta, 30-2, pp. 139-147.

GLEASON, H. A. G. (1979): "Why Grammars Don't Help Very Much," Meta, 25-4, pp. 409-420.

GREGORY, M. J. (1980): "Perspectives on Translation from the Firthian Tradition," Meta, 25-4, pp. 455-466.

JAKOBSON, R. (1959): "Linguistics Aspects of Translation," in R. A. Bower, ed.: On Translation, Harvard, pp. 232-239.

JAMES, C. (1989): "Genre Analysis and Translation," Target, 1, pp. 29-42.

KACHROO, B. (1984): "Textual Cohesion and Translation," Meta, 29-2, pp. 128-134.

KELKAR, A. (1985): “To Translate or not to Translate?," 30-3, pp. 211-233. 
KLEIN-LATAUD, Ch., and TATILON, C. (1986): "La traduction des structures grammaticales", Meta 31-4, pp. 370-376.

KOMISSAROV, V. (1987): "The Semantic and the Cognitive in the Text: A Problem in Equivalence," Meta, 32-4, pp. 416-419.

KUSSMAUL, P. (1985): “The Degree of Semantic Precision in Translation," Babel, 31-1, pp. 12-19.

LANDHEER, R. (1989): "L'ambiguité; un défi traductologique", Meta, 34-1, pp. 33-43.

LANDSBERG, M. E. (1975): “Translation Theory: Appraisal of Some General Problems," 21-4, pp. 235-251.

*LEDERER, M. (1976): “Synecdoque et traduction”, Etudes de linguistique appliquée, 24, pp. 13-41.

LOTFIPOUR-SAEDI, K. (1990): "Discourse Analysis and the Problem of Translation Equivalence," Meta, 35-2, pp. 389-397.

*MOSSOP, B. (1983): "The Translator as Rapporteur: A Concept for Training and Self-Improvement," Meta, 28-3, pp. 235-251.

NEWMARK, P. (1977): "Communicative and Semantic Translation," Babel, 23-4, pp.163-180.

NEWMARK, P. (1980): “The Translation of Metaphor," Babel, 24-2, pp. 93-100.

NIDA, E. (1977): "The Nature of Dynamic Equivalence in Translating," Babel, 23-3, pp. 99-103.

NIDA, E. (1978): "The Setting of Translation: A Largely Overlooked Factor in Translation," Babel, 24-2, pp. 114-117.

ROBERTS, R. (1987): "L'équivalence en traduction", Meta, 32-4, pp. 392-402.

SCHOGT, H. G. (1981): "Analyse sémantique immanente, référence et traduction", Meta, 26-2, pp. 117-122.

*SELESKOVITCH, D. (1976): "Traduire: de l'expérience aux concepts", Études de linguistique appliquée, 24, pp. 64-91.

SELESKOVITCH, D. (1980): "Pour une thérie de la traduction inspirée de sa pratique", Meta, 25-4, pp. 401-408. SELESKOVITCH, D. (1990): "La traduction des hyperonymes et autres termes de grande extension", Meta, 35-1, pp. 91-95.

SIMPSON, E. (1978): “À propos de deux points controversés en traductologie”, Babel, 24-3, pp. 118-123.

THIEN, T. T. (1983): "Linguistique et traduction: Propos du traducteur", Meta, 28-2, pp. 130-152.

TRUFFAULT, L. (1980): "Les enjeux de l'ambivalence dans l'opération traduisante", Meta, 25-4, pp. 430-436.

VLAGGIO, S. (1987): "Teaching Translation to Beginners, A Method Preached," Proceedings of the 28th Annual Conference of the ATA, N.J., pp. 379-392.

VIAGGIO, S. (1988): "Teaching Translation to Beginners, A Preach Continued," Proceedings of the 29th Annual Conference of the ATA, N.J., pp. 339-351.

*VINAY, J.-P. (1980): "Statistiques de la servitude en matière de traduction", Meta, 25-4, pp. 447-454.

WILLS, W. (1985): "Rhetorical and Stylistic Issues in Translation Pedagogy," Meta, 30-3, pp. 224-234. 